\title{
ACHIEVING FOOD SECURITY THROUGH RETAILING: A CASE STUDY
}

\author{
Muhammed Basheer MP, University of Calicut, India \\ R. Vasanthagopal, University of Kerala, India \\ Rebecca Abraham, Nova Southeastern University, U.S.A.
}

dx.doi.org/10.18374/JIFE-20-3.4

\begin{abstract}
Governments and aid organizations have responded to rising food prices in developing countries by subsidizing agricultural inputs, including fertilizers, seeds, and farm equipment, increasing import subsidies, or eliminating export subsidies. This paper sets forth an alternative solution through government intervention in the distribution of food. The state government of Kerala, India, created two retail agencies of supermarkets (called Supplyco) and vertically integrated distribution (called Consumerfed) to reduce food insecurity for low income consumers. This paper evaluates their performance by examining customer satisfaction through surveys of Supplyco's and Consumerfed's customers. Findings include Supplyco's ability to provide retail outlets at convenient locations, while maintaining a buffer stock during periods of peak demand. Consumerfed was recognized for its ability to reduce prices, partly by regulating open market prices, and partly by acting as an agent of the government. The paper contributes to the literature on the government's ability to achieve food security through retailing. It offers a culturally sensitive solution to approaching the problem of food insecurity in a developing country. This approach may be extended to solving food price inflation in other developing countries.
\end{abstract}

Keywords: food security, government intervention, food retailing, development, Kerala 